e-issn: $2229-8568$

\title{
Assessment of ICT Usage in Estate Surveying and Valuation Practice in Nigeria
}

\author{
Wasiu Akinola Adedamola ${ }^{1 *}$, Joseph Oyewale Oyedeji ${ }^{1}$ and Toyin Funmilayo Faturoti ${ }^{1}$ \\ ${ }^{1}$ Department of Estate Management,College of Environmental Sciences, Bells University of Technology, Ota, \\ Ogun State. \\ *Email: wasiuadedamola@gmail.com
}

\begin{abstract}
To operate in a dynamic environment, the success of real estate companies' hinges, to a large extent, on their ability to deliver innovative, user-accepted products and services in a timely, seamless manner. The need for Information and Communication Technology (ICT) for secure, safe, and adequately serviced estate surveying and valuation practice is very pertinent to the profession. Therefore, this study assessed the level of usage of ICT in estate surveying and valuation practice in the study area with the view of improving real estate service delivery in Lagos Island, Nigeria. Data were gathered through a survey conducted with registered estate firms in Lagos Island, Nigeria. The data from the responses that were gathered were analysed using descriptive statistics and Relative Importance Index (RII) ranking. Findings revealed that the majority of the respondents are adopting ICT in carrying out their estate surveying and valuation practice. In addition, the results of the study established a positive correlation between improving estate surveying practice and the adoption of ICT. Furthermore, the findings also revealed the level of conversant with the use of real estate software has the highest RII while Artificial Intelligence software has the lowest RII. The study concluded that it is without a doubt that the degree of application of ICT in real estate has been very significant, but there are still barriers that limit its application within the sector. The study recommends that the estate surveyors \& valuers in academia who are responsible for coaching core departmental courses include ICT into several aspects of the curriculum.
\end{abstract}

Keywords: Estate Surveying and Valuation Practice, ICT, Real Estate Software, Technology

\subsection{INTRODUCTION}

The Information and Communication Technology (ICT) is referred to as the infrastructure and invention development that facilitates the assortment, storing, analysing and implementation of information that may be communicated electronically (Sing, 2002). Rodriguez \& Wilson (2002) quoted the World Bank definition of ICT as the series of activities that expedites electronic means of planning, collecting, storing, processing, communicating and displaying information for better improvement. The stride of changes fetched about by the introduction of several ICT tools developments have directed to reorganisation, changes in work form, and demand for innovative skills and job retraining in every career (Ogunsola and Aboyade, 2005). Furthermore, ICT has an excellent substantial influence on the living and sustaining situation of people globally (Ogunsola and Aboyade, 2005).

Information is very crucial to the estate surveying and valuation practice. However, ICT is a key tool for marketing and information dispersion. As a real estate marketing tool, ICT gives wide- 
e-issn: $2229-8568$

ranging exposure to grasp probable clients in estate surveying and valuation practice. Furthermore, information gathering is faster and more accurate with the use of ICT. Besides, it is perhaps the cheapest mode to sell real estate products (Olukolajo et al., 2015).

Despite the extensive use and applicability of ICT to improve estate surveying and valuation practice managerial performance, there are numerous impairments that hinder its disposition in most estate surveying and valuation firms (Oyetunji et al., 2018). Some of the hard-hitting limitations are persistent of outdated verbalised culture and traditions that accentuate confrontational information exchanges, low ICT competencies of workers, deficiency of monetary resources for ICT procurement, dearth of adherence to estate surveying and valuation ICT standards, the high fee of internet admittance and poor internet linking services, great cost of hardware plus knowledge about the price and financial benefits of ICT investments (Adedamola, 2020). These constrictions deter estate surveying and valuation firms from spending timeously and sufficiently in ICT systems, irrespective of the benefits and opportunities that the organisation promises (Adedamola, 2020).

ICT usages in form of hardware and software applications are now accessible to support numerous facets of estate surveying and valuation practice. Despite recent adoption and the increasing deployment of ICT in estate surveying and valuation practice worldwide, there is the restriction to its extensive placement in the Nigerian Estate Surveying and Valuation sector, the extent of which is still unidentified. The above gap in knowledge is what this study aimed to explore. The study, therefore, focused on the assessment of ICT usage in estate surveying and valuation practice in Nigeria. Nevertheless, the geographical scope of the study is limited to Lagos Island, Nigeria. This is because it is the largest commercial centre in Nigeria where the huge majority of Nigeria's estate surveying and valuation professional and firms are focused. After all, the conurbation is unarguably measured as the greatest vivacious and energetic property market in Nigeria.

\subsection{LITERATURE REVIEW}

\subsection{Evolution of ICT in Nigeria}

Nigeria is the most populous country in Africa. The country has a huge urban growth rate at present time. This is a good condition for the upsurge of Internet usage, and the usage of ICT technology in such areas as education, health, agriculture, business, government, and transportation. Such development has been observed over the last 15 years. The National Information Technology Policy was approved in March of 2001. There also appeared such organisation as National Information Technology Development Agency which made Nigeria an ICT-capable country and the main player in the ICT in Africa. Nigeria started to use ICT technologies as a catalyst for sustainable development and competitiveness in the international arena.

Based on this, the introduction of ICT in other segments of the economy like banks, insurance, health, etc., has headed to great transformation in the conventional working way, method, or practice of estate surveying and valuation professionals in the nation (Kakulu, 2008). The speedy acceptance of ICT by the Nigerian banking sector in their day-to-day tasks and services has brought limelight to every professional of which Nigerian Estate Surveyors and Valuers (NIESV) always play a significant role (Kakulu, 2008). The Estate Surveyors and Valuers in developing countries in which Nigeria is among sluggishly embraced ICT through the implementation of various ICT tools such as Geographical Information System (GIS), Electronic Data Base Management (EDBM), Land Information System (LIS), and the use of Automated Valuation Model (AVM) among other ICT tools (Babawale, 2012).

\subsection{Application of ICT in Real Estate Practices}

ICT partakes recently in what appears to be a revolution in estate surveying and valuation practice in Nigeria (Adedamola, 2020). Estate surveying and valuation practitioners are progressively advancing in technology hardware and software. Estate surveying and valuation practice are at the heart of intense changes fetched about by online technology and the improved availability of ICT tools 
e-issn: $2229-8568$

(Oyetunji et al., 2018). A large part of estate surveying and valuation practitioners are using websites. Therefore, any estate surveying and valuation firm with computer and internet services can get access to estate surveying and valuation information which cut across sales, letting, valuation, maintenance, management of properties among others. A crucial component in the changes taking place in the establishment of an industry standard to brand the altercation of data between estate surveying and valuation practitioners, property inspectors, and other practice faster and easier.

According Tse et al. (2002) the interest in online internet searches by clients has led most estate surveying and valuation professionals to alter the way they operate their estate surveying and valuation businesses. Estate surveying and valuation brokers, agents, managers, maintenance, valuers, developers, etc. can use the ICT tools and internet to send up-to-date information to prospective clients at a very stumpy cost, precisely and swiftly. The ICT tools and internet can also aid estate surveying and valuation practitioners to increase sales, reduce time, cut costs on numerous transactions and offer an outstandingly higher level of service to both clients and sellers. Using virtual "model" houses can be dispersed on CD-ROM, very much like house brochures, and the model can be opened unswervingly through the internet service.

\subsection{Importance of ICT to Real Estate Practice}

Information and Communication Technologies which embrace radio and television, with advanced digital technologies such as computers and the internet have been recognised as probable significant tools for better and improve professional conduct and practice. Once ICT are used appropriately, they can help in expanding access to estate surveying and valuation profession, reinforce the significance of estate surveying and valuation profession to the progressively improve, digital workplace, and increase quality by aiding estate surveying and valuation practice into an energetic procedure allied to real life situation (Babawale, 2012).

\subsection{Advantageous and Disadvantages of ICT in Real Estate}

The global framework that guides this research focuses on the level of uses of ICT tools that are endorsed by individuals who alter the conduct of their estate surveying and valuation work in response to the accessibility of ICT. These alterations include replacement of some selected activities by an automated system (e.g., database management, argus valuation) or intensifications in some activities that are made inexpensive through the support of ICT (e.g., GIS for the locational map instead of physical measurement and daily automated searches for potential properties instead of physical search). ICT could make available applicable information and communication technology that changes the source for policymaking or contacts to prospective clients on various activities connected to estate surveying and valuation. The personal or specific level of use of ICT leads to changes in the work done of estate surveyors and valuers to which the job is completed. The effects of ICT marked themselves first as part of changes to managerial progressions and ultimately to changes in structural edifices. Managerial structures include how people are ordered for broadcasting and broadcasting of information along with organisational processes which reproduce the choice and sequencing of tasks to get done with projected outcomes. Changes in process of ICT have implications for estate surveying and valuation organisations and value-chains (Babawale, 2012). The manufacturing arrangement of ICT includes contribution and separation of effort among estate surveying and valuation companies (i.e. the position of real estate firms and their boundaries). The manufacturing of ICT value-chain is seen as a process extensive across estate surveying and valuation firms.

Today, the estate surveying and valuation practice is dealing with a figure of encounters such as real estate agency problem, property maintenance problem, escalating project cost, prolonged construction period, market value problem and real estate appraisal problem (Adedamola 2020). ICT grasps the key which is not only meant to address some of these issues but also a capacity for the real estate sector to respond to the shifting market conditions more efficiently and competently (Confederation of Indian Industry, 2012). The extensive disposition of ICT through the numerous effective segments is predictable to allow the real estate sector to rationalise estate surveying and 
e-issn: $2229-8568$

valuation allied procedures and increase the quality, cost-effectiveness and timeliness of service delivery, while also ensuring that the real estate firms are settled and accomplished in contemplation of long-term sustainability and location related concerns for estate surveying and valuation practice.

\subsection{Experience of ICT Application in Real Estate Practices from Past Studies}

Oyetunji et al., (2018) examined ICT application status in the Nigerian Estate Surveying and Valuation Practice, using tables, frequencies, and weighted mean scores and Chi-square test. The results from the findings showed that there are five (5) top-most used softwares and they are all used for general purposes (i.e. Email, Microsoft Word, Microsoft Excel, PowerPoint and Adobe Reader).

Babatunde et al., (2018) carried out a study on the impact of ICT on real estate agency in Lagos Metropolis, Nigeria, using tables, mean ranking, relative influence index and analysis of variance all for the research and the results showed that the usage of ICT has impacted positively on all aspect of real estate but most importantly, the real estate agency transactions by promoting company's brand thereby snowballing the level of patronage.

Ibisola et al. (2015) carried out a study on the relevance and application of ICT in estate surveying and valuation in Ogun State, Nigeria using Relative Importance Index (RII) and the result showed that the estate surveyors and valuers are sensible of the existence of the numerous ICT applications and devices but have not been using them effectively to promote their practice.

\subsection{THE STUDY AREA}

Lagos Island is located within Lagos State. Lagos Island is the main principle and the central local government area (LGA) in Lagos, Lagos State. It is one of the parts of the Lagos Division. From the preliminary 2006 Nigerian population census, the LGA in Lagos Island had a population of 209,437 covers an area of $8.7 \mathrm{~km}^{2}$. The LGA only covers the western half of Lagos Island; the eastern half is the second half and it is simply referred to as Lagos Island East LCDA.

Lagos Island is connected to the mainland by three great bridges which cut across Lagos Lagoon to the region of Ebute Metta. The bridge is also linked to the neighbouring Island of Ikoyi and Victoria Island. The Lagos Island harbour district of Apapa faces the western side of the island. Almost 60 percent of the country's industrial and commercial activities are dwelling in the city of Lagos which made Lagos Island the main core for the location of headquarters of national and global companies as well as the complex business without excluding professional services that support numerous organisation. From the latest directory of the Nigerian Institution of Estate Surveyors and Valuers (NIESV), it shows that Lagos has the highest number of registered estate surveying and valuation practitioners with 126 located on Lagos Island as at the time of this research from which most of the estate surveying and valuation professionals have their head offices on the Lagos Island and branches on the mainland or city this is the basis for chosen Lagos Island as the study area. 


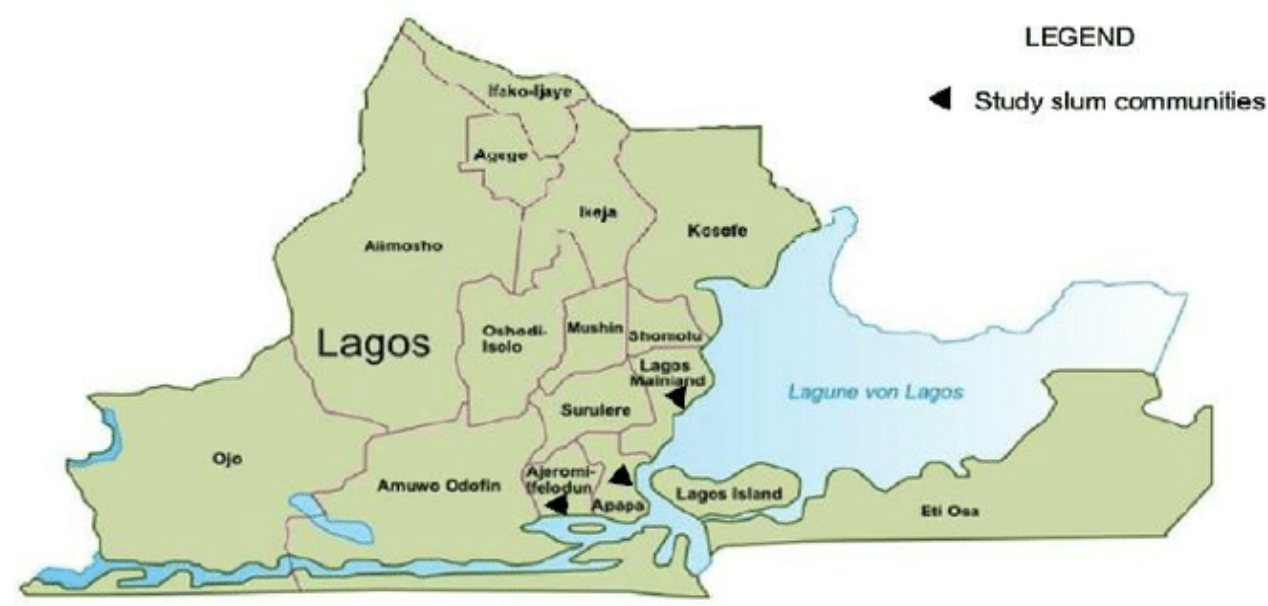

Figure 1: Map of Lagos state showing the sixteen Local Government Areas Source: Field Survey, 2020

\subsection{METHODOLOGY}

A quantitative research approach that evaluates and measures the impact of a variable on another variable was employed for this study. Essentially, since the impact of the deployment of ICT on real estate practice is the focus of this research, it becomes relevant that such a methodological approach is used. Further is the fact that similar studies, such as Oyetunji et al., (2018); Babatunde et al., (2018); and Ibisola et al., (2015) employed the same method.

The Estate Surveyors and Valuers as real estate facility providers were chosen for this study. The core purpose for this is that in Nigeria today, estate surveyors and valuers are the only professionals that are recognised by Nigeria Constitution or law to practice, and operate on all matters relating to land and landed properties and that they operate under the umbrella body known as "The NIESV". The 13th edition directory which is the most recent from the NIESV, Lagos State branch directory, listed 126 practicing firms on Lagos Island form the sample frame as well as the sample size used for this study.

Based on the directory, a total number of 87 registered real estate firms were randomly selected on Lagos Island, Nigeria out of the 126 registered real estate firms, for the sample size. This represents 69 percent of the practicing firms in Lagos Island, Nigeria and was measured to form a depiction of the total population in the study area. Structured questionnaires were administered through selfadministration to the respondents, from which only 79 (representing 90.8 percent response rate) were collected and used for this research.

The data was analysed using descriptive techniques such as frequency tables, percentages, charts, and the Relative Importance Index (RII) ranking model with the use of the Likert scale. The relative Importance Index (RII) is calculated for each of the indicators used to assess and ranked accordingly in ascending order. The RII derived review the importance of each indicator used for the assessment. It is used for survey authorising and deployment, data scaling, data gathering, data removal, text analytics, statistical analysis, collaboration, deployment and ranking from "most" to "least" (Likert scale and ranking scoring services). The data collected were analysed and presented using simple descriptive percentage frequency tables and charts. A correlation was done using the Pearson product moment correlation (PPMC) statistical instrument to test for the relationship between the size of firms and the use of ICT. 
e-issn: $2229-8568$

\subsection{FINDINGS}

The findings of the survey conducted among the practitioners in estate surveying and valuation practice in Nigeria are shown in the subsequent sections. The survey sought to assess the level of usage of ICT tools by estate surveyors and valuers in Lagos Island, Nigeria.

\subsection{Descriptive Statistics Analysis}

Table 1 below illustrate the frequency distribution, table and ranking, of certain variables with their percentages accordingly, showing the analysis of the various data sets below.

Table 1: Position of ICT Tools in Sustaining Estate Surveying \& Valuation Practice

\begin{tabular}{lll}
\hline Response & Frequency & Percentage \\
\hline Yes & 79 & 100.0 \\
No & - & - \\
Total & $\mathbf{7 9}$ & $\mathbf{1 0 0 . 0}$ \\
\hline & Source: Field Survey, 2020
\end{tabular}

Table 1 also represents the position of ICT tools in sustaining and enhancing estate surveying and valuation practice as a way to assess the ICT tools as applicable to this practice. All the practitioners agree that ICT tools are essential in sustaining the practice. This will help the researchers to assess the level of usage.

Table 2: Contribution of ICT Tools towards the Development and Growth of Estate Surveying \& Valuation Practice

\begin{tabular}{cll}
\hline Response & Frequency & Percentage \\
\hline Yes & 79 & 100.0 \\
No & - & - \\
Total & $\mathbf{7 9}$ & $\mathbf{1 0 0 . 0}$ \\
\hline
\end{tabular}

Source: Field Survey, 2020

Table 2 shows that all the respondents indicated that there is a contribution of ICT tools towards the development and growth of estate surveying \& valuation practice. This evidenced that ICT has contributed immensely towards the development and growth of estate surveying and valuation practice.

Table 3: Extent of Application of ICT in Real Estate Office

\begin{tabular}{lccccccc}
\hline DETERMINANTS & $\begin{array}{c}\text { VH } \\
(5)\end{array}$ & $\begin{array}{c}\mathrm{H} \\
(4)\end{array}$ & $\begin{array}{c}\text { M } \\
(3)\end{array}$ & $\begin{array}{c}\text { L } \\
(2)\end{array}$ & $\begin{array}{c}\text { VL } \\
(1)\end{array}$ & RII & $\begin{array}{c}\text { RANKIN } \\
\text { G }\end{array}$ \\
\hline $\begin{array}{l}\text { Preparing letters, reports and other } \\
\text { documents }\end{array}$ & 320 & 40 & 15 & - & - & 4.75 & $1^{\text {ST }}$ \\
Sending mails & & & & & & & \\
$\begin{array}{l}\text { Advertising of properties } \\
\text { Sourcing of property }\end{array}$ & 245 & 80 & 30 & - & - & 4.49 & $2^{\text {nd }}$ \\
\hline
\end{tabular}

Source: Field Survey, 2020

Table 3 above shows the analysis of responses on the extent of application of ICT in operating real estate firm. Some of the uses of the ICT tools listed were ranked and the finding revealed that preparing letters, reports and other documents was ranked first (with RII 4.75) while sending mails was ranked second (RII of 4.49). However, advertising of properties was ranked the third with RII of 4.43, while the sourcing of property was the least considered extent of ICT tools occupying the fourth position at the bottom of the ranking table with RII of 3.94. This is needed by the researchers to determine the extent 
e-issn: $2229-8568$

to which the ICT is being used in estate surveying and valuation practice. Based on this result it was discovered ICT has not been utilised extensively.

Table 4: Rating of Real Estate Practice with ICT Tools Compare to Non-use

\begin{tabular}{lllll}
\hline Response & Frequency & Percentage & Mean & Rate \\
\hline Excellent Change & 42 & 53.2 & .53 & $1^{\text {st }}$ \\
Little Change & 23 & 29.1 & .29 & $2^{\text {nd }}$ \\
No Change & 9 & 11.4 & .11 & $3^{\text {rd }}$ \\
Worst & 5 & 6.3 & .06 & $4^{\text {th }}$ \\
Total & $\mathbf{7 9}$ & $\mathbf{1 0 0 . 0}$ & & \\
\hline
\end{tabular}

Source: Field Survey, 2020

Most of the respondents stated that there has been a significant positive change in their estate surveying and valuation practice since the use of ICT tallying with the responses of Table 4, which stated likewise. $53.2 \%$ stated that there has been an excellent change, while $29.1 \%$ stated that there has been a little change when compared to the non-use of ICT by estate surveying and valuation practitioners. The result shows that the usage of ICT in Estate Surveying and Valuation Practice has brought excellent changes into the practice.

Table 5: Degree of ICT Adherence in Estate Surveying \& Valuation Practice

\begin{tabular}{lll}
\hline Response & Frequency & Percentage \\
\hline Very High & 11 & 13.9 \\
High & 16 & 20.3 \\
& & \\
Moderate & 42 & 53.2 \\
Low & 8 & 10.1 \\
Very Low & 2 & 2.5 \\
Total & $\mathbf{7 9}$ & $\mathbf{1 0 0 . 0}$ \\
\hline
\end{tabular}

Source: Field Survey, 2020

As indicated in Table 5 above, most of the respondents indicated that ICT formulates a moderate adherence towards the improvement of the real estate practice. $13.9 \%$ of the respondents stated that ICT has a very high degree of adherence on the general real estate practice, while $20.3 \%$ of the respondents also indicated that there is a high degree of adherence of ICT on estate surveying and valuation practice. On the other hand, $53.2 \%$ of the respondents stated that the degree of adherence has been moderate that not high nor low but at average, while $10.1 \%$ and $2.5 \%$ stated that the degree of the ICT adherence has a low and very low impact on general real estate practice. It can be deduced from the result that the degree of ICT adherence in estate surveying and valuation practice is not at the best but there is greater improvement compared to the initial adherence of ICT in the country.

Table 6: Level of Conversant with the Use of Real Estate Software

\begin{tabular}{|c|c|c|c|c|c|c|c|}
\hline DETERMINANTS & $\begin{array}{l}\mathrm{HC} \\
(5) \\
\end{array}$ & $\begin{array}{l}\mathrm{C} \\
(4)\end{array}$ & $\begin{array}{l}U \\
(3)\end{array}$ & $\begin{array}{l}\mathrm{LC} \\
(2)\end{array}$ & $\begin{array}{l}\mathrm{NC} \\
(1) \\
\end{array}$ & RII & $\begin{array}{l}\text { RANKIN } \\
\text { G }\end{array}$ \\
\hline MS Excel & 270 & 100 & - & - & - & 4.68 & $1^{\mathrm{ST}}$ \\
\hline MS Office Package & 150 & 156 & 15 & 10 & - & 4.19 & $2^{\text {nd }}$ \\
\hline Data Base Management & 185 & 68 & 30 & 30 & - & 3.96 & $3^{\text {rd }}$ \\
\hline Corel Draw & 170 & 80 & 30 & 30 & - & 3.92 & $4^{\text {th }}$ \\
\hline GIS & 150 & 80 & 60 & - & 18 & 3.90 & $5^{\text {th }}$ \\
\hline AutoCAD & 195 & 44 & 15 & 30 & 18 & 3.82 & $6^{\text {th }}$ \\
\hline Eva Property.com & 50 & 145 & 90 & 10 & 5 & 3.80 & $7^{\text {th }}$ \\
\hline
\end{tabular}




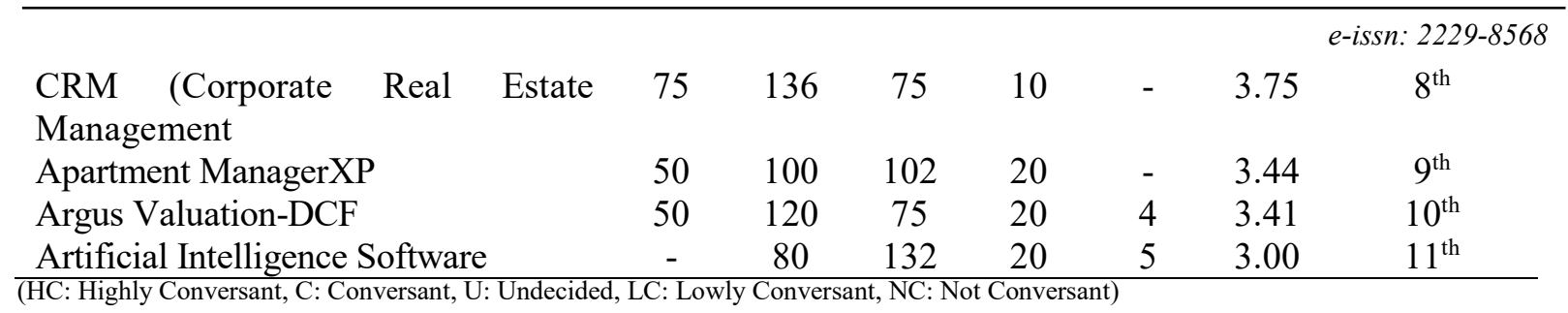

Source: Field Survey, 2020

Table 6 shows an analysis of responses on the level of conversant with the usage of real estate software. The major real estate software listed were ranked and the study revealed that MS Excel was ranked first (with RII of 4.68), along with MS Office Package that was ranked second, having RII of 4.19. However, Data Base Management, Corel Draw, GIS, and AutoCAD were ranked the $3^{\text {rd }}, 4^{\text {th }}, 5^{\text {th }}$ and $6^{\text {th }}$ level of conversant with RII of 3.96, 3.92, 3.9 and 3.82 respectively. In addition, Eva Property.com, CRM (Corporate Real Estate Management, Apartment ManagerXp, Argus Valuation-DCF and Artificial Intelligence Software took the $7^{\text {th }}, 8^{\text {th }}, 9^{\text {th }}, 10^{\text {th }}$ and $11^{\text {th }}$ positions at the bottom of the ranking table with RII of 3.80, 3.75, 3.44, 3.41 and 3.0 respectively. The analysis helps the researchers to determine the level of conversant of estate surveying and valuation practice with the use of ICT in Lagos, Nigeria.

\subsection{The Use of Software in Estate Surveying \& Valuation Practice}

The findings on the use of software that are applicable in the estate surveying and valuation practice are shown in the following tables. The responses are ranked in accordance to the following levels: HU: Highly Utilised, U: Utilised, I: Indifferent, RU: Rarely Utilised, NU: Not Utilised.

Table 7a: Office Administration

\begin{tabular}{|c|c|c|c|c|c|c|c|}
\hline DETERMINANTS & $\begin{array}{l}\mathrm{HU} \\
(5)\end{array}$ & $\begin{array}{l}U \\
(4)\end{array}$ & $\begin{array}{l}\text { I } \\
\text { (3) }\end{array}$ & $\begin{array}{l}\text { RU } \\
(2)\end{array}$ & $\begin{array}{l}\mathrm{NU} \\
(1)\end{array}$ & RII & $\begin{array}{l}\text { RANKIN } \\
\mathrm{G}\end{array}$ \\
\hline MS Office Package & 210 & 140 & 6 & - & - & 4.51 & $1^{\mathrm{ST}}$ \\
\hline MS Excel & 200 & 112 & 9 & 16 & - & 4.27 & $2^{\text {nd }}$ \\
\hline Corel Draw & 100 & 76 & 18 & 48 & 10 & 3.19 & $3^{\text {rd }}$ \\
\hline Data Base Management & 110 & 92 & - & 20 & 24 & 3.11 & $4^{\text {th }}$ \\
\hline GIS & 100 & 72 & - & 60 & 11 & 3.08 & $5^{\text {th }}$ \\
\hline $\begin{array}{l}\text { CRM (Corporate Real Estate } \\
\text { Management }\end{array}$ & - & 4 & - & 93 & 31 & 1.61 & $6^{\text {th }}$ \\
\hline Apartment ManagerXP & - & - & 12 & 52 & 49 & 1.43 & $7^{\text {th }}$ \\
\hline AutoCAD & - & - & - & 56 & 51 & 1.35 & $8^{\text {th }}$ \\
\hline Eva Property.com & - & - & - & 8 & 75 & 1.05 & $9^{\text {th }}$ \\
\hline Argus Valuation-DCF & - & - & - & - & 79 & 1.00 & $10^{\text {th }}$ \\
\hline Artificial Intelligence Software & - & - & - & - & 79 & 1.00 & $10^{\text {th }}$ \\
\hline
\end{tabular}

Source: Field Survey, 2020

Table 7a shows analysis of responses on the use of software as its applicable in Estate Surveying practice in office administration and some of the major real estate software listed were ranked. The findings show that MS Office Package, the most utilised factor with RII of 4.51 was ranked first, along with MS Excel that was ranked second ( RII of 4.27). However, Corel Draw, Data Base Management, GIS, and CRM (Corporate Real Estate Management were ranked the $3^{\text {rd }}, 4^{\text {th }}, 5^{\text {th }}$ and $6^{\text {th }}$ level of use with RII of 3.19, 3.11, 3.08 and 1.61 respectively, while Apartment ManagerXp, AutoCAD, Eva Property.com, Argus Valuation-DCF and Artificial Intelligence Software occupied the $7^{\text {th }}, 8^{\text {th }}, 9^{\text {th }}, 10^{\text {th }}$ and $10^{\text {th }}$ positions at the bottom of the ranking table with RII of $1.43,1.35,1.05,1.00$ and 1.00 respectively. The analysis clearly had shown the usage of software in office administration for estate surveying and valuation practice. 
Table 7b: Property Management

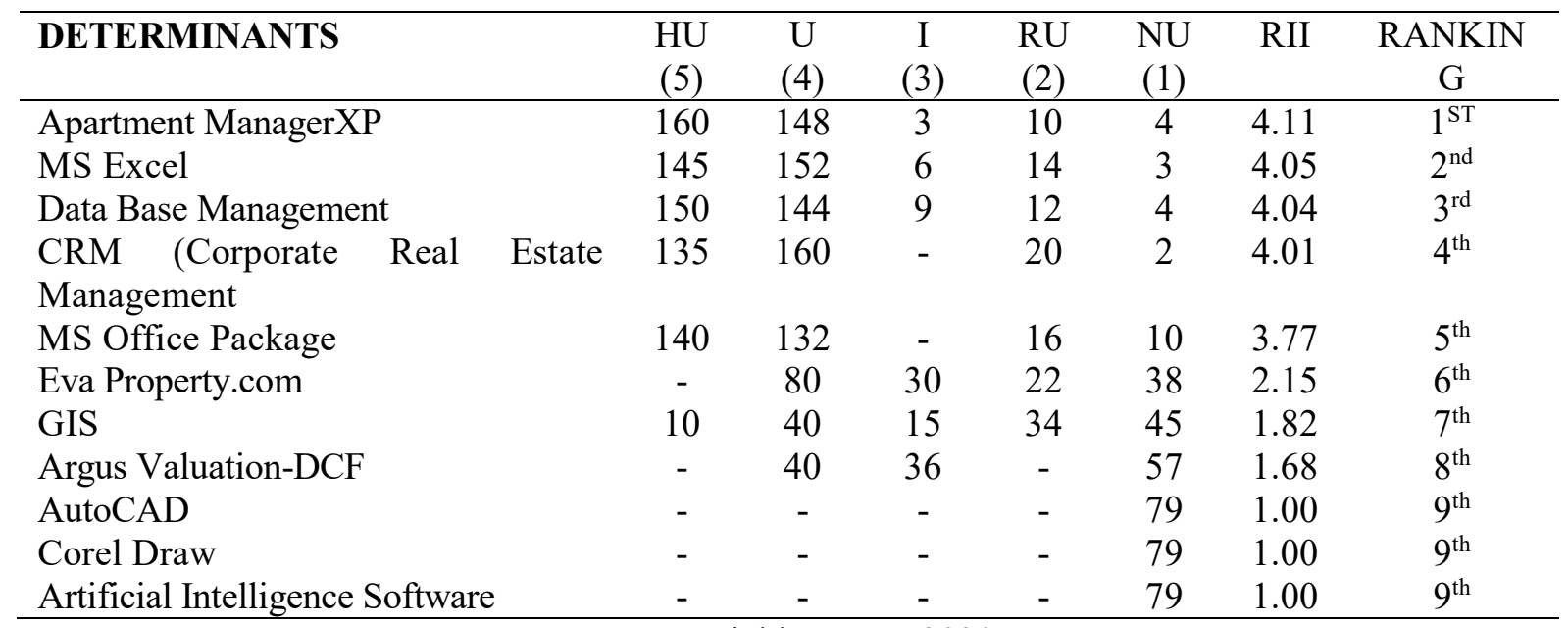

Source: Field Survey, 2020

Table $7 \mathrm{~b}$ shows analysis of responses on the use of software as its applicable in estate surveying practice in property management. Some of the major real estate software listed were ranked and the findings show that, Apartment ManagerXp, is the most utilised factor with RII of 4.11 along with MS Excel that was ranked $2^{\text {nd }}$ (RII of 4.05). However, Data Base Management, CRM (Corporate Real Estate Management, MS Office Package, and Eva Property.com, were ranked the $3^{\text {rd }}$, $4^{\text {th }}, 5^{\text {th }}$ and $6^{\text {th }}$ level of use with RII of 4.04, 4.01, 3.77 and 2.15 respectively. GIS, Argus Valuation-DCF, AutoCAD, Corel Draw, and Artificial Intelligence Software were ranked $7^{\text {th }}, 8^{\text {th }}, 9^{\text {th }}, 9^{\text {th }}$ and $9^{\text {th }}$ at the bottom of the ranking table with RII of 1.82, 1.68, 1.00, 1.00 and 1.00 respectively.

Without a doubt, the table above clearly spelt out the rate to which various software is being used to run the property management sections of the estate surveying and valuation practice in Nigeria. From the result, we can now identify the most important software to property section to the least software in the same section.

Table 7c: Estate Agency

\begin{tabular}{lccccccc}
\hline DETERMINANTS & $\begin{array}{c}\text { HU } \\
(5)\end{array}$ & $\begin{array}{c}\text { U } \\
(4)\end{array}$ & $\begin{array}{c}\text { I } \\
(3)\end{array}$ & $\begin{array}{c}\text { RU } \\
(2)\end{array}$ & $\begin{array}{c}\text { NU } \\
(1)\end{array}$ & RII & $\begin{array}{c}\text { RANKIN } \\
\text { G }\end{array}$ \\
\hline MS Office Package & 210 & 128 & 6 & 6 & - & 4.43 & $1^{\text {ST }}$ \\
MS Excel & 190 & 140 & 12 & 4 & - & 4.38 & $2^{\text {nd }}$ \\
Data Base Management & 160 & 112 & 6 & 10 & 12 & 3.80 & $3^{\text {rd }}$ \\
Apartment ManagerXP & 180 & 76 & 12 & - & 20 & 3.65 & $4^{\text {th }}$ \\
GIS & 60 & 36 & - & 36 & 40 & 2.18 & $5^{\text {th }}$ \\
Corel Draw & 10 & 16 & 75 & 32 & 32 & 2.09 & $6^{\text {th }}$ \\
AutoCAD & - & 68 & 28 & - & 48 & 1.82 & $7^{\text {th }}$ \\
Eva Property.com & 30 & 8 & 15 & 32 & 52 & 1.61 & $8^{\text {th }}$ \\
CRM (Corporate Real Estate Management & 20 & 12 & - & 20 & 60 & 1.58 & $9^{\text {th }}$ \\
Argus Valuation-DCF & - & - & - & - & 79 & 1.00 & $10^{\text {th }}$ \\
Artificial Intelligence Software & - & - & - & - & 79 & 1.00 & $10^{\text {th }}$ \\
\hline
\end{tabular}

Source: Field Survey, 2020

Table 7c shows an analysis of responses on the use of software as its applicable in estate surveying \& valuation practice in estate agency. Some of the major real estate software listed were ranked and the findings show that MS Office Package, was ranked first with RII of 4.43, along MS Excel which was ranked $2^{\text {nd }}$ with RII of 4.38. However, Data Base Management, Apartment ManagerXp, GIS, and Corel Draw were ranked the $3^{\text {rd }}, 4^{\text {th }}, 5^{\text {th }}$ and $6^{\text {th }}$ level of use with RII of $3.80,3.65,2.18$ and 2.09 
e-issn: $2229-8568$

respectively. On the other hand, AutoCAD, Eva Property.com, CRM (Corporate Real Estate Management, Argus Valuation-DCF, and Artificial Intelligence Software were ranked the $7^{\text {th }}, 8^{\text {th }}, 9^{\text {th }}, 9^{\text {th }}$ and $9^{\text {th }}$ at the bottom of the ranking table with RII of 1.82, 1.61, 1.58, 1.00 and 1.00 respectively. Agency is one of the important sections in Estate Surveying and Valuation Practice. The result above explained the level of utilisation of the various softwares to the section from the most used to less used.

Table 7d: Valuation

\begin{tabular}{lccccccc}
\hline DETERMINANTS & HU & U & I & RU & NU & RII & RANKIN \\
& $(5)$ & $(4)$ & $(3)$ & $(2)$ & $(1)$ & & G \\
\hline MS Excel & 235 & 120 & - & 4 & - & 4.54 & $1^{\text {sT }}$ \\
MS Office Package & 180 & 152 & 12 & 2 & - & 4.38 & $2^{\text {nd }}$ \\
Data Base Management & 80 & 80 & 9 & 28 & 26 & 2.82 & $3^{\text {rd }}$ \\
Corel Draw & 45 & 60 & 30 & 50 & 20 & 2.59 & $4^{\text {th }}$ \\
AutoCAD & 55 & 20 & 21 & 52 & 30 & 2.25 & $5^{\text {th }}$ \\
CRM (Corporate Real Estate & - & 56 & - & 62 & 34 & 1.92 & $6^{\text {th }}$ \\
Management & & & & & & & \\
Argus Valuation-DCF & 30 & 40 & - & 30 & 48 & 1.87 & $7^{\text {th }}$ \\
GIS & 40 & 12 & - & 56 & 40 & 1.87 & $8^{\text {th }}$ \\
Eva Property.com & - & - & - & - & 79 & 1.00 & $9^{\text {th }}$ \\
Apartment ManagerXP & - & - & - & - & 79 & 1.00 & $9^{\text {th }}$ \\
Artificial Intelligence Software & - & - & - & - & 79 & 1.00 & $9^{\text {th }}$ \\
\hline
\end{tabular}

Table $7 \mathrm{~d}$ shows analysis of responses on the use of software as its applicable in estate surveying \& valuation practice in valuation. Some of the major real estate software listed were ranked and the findings showed that MS Excel, was ranked first with RII of 4.54, along with MS Office Package which was ranked $2^{\text {nd }}$ having RII of 4.38. In addition, Data Base Management, Corel Draw, AutoCAD, and CRM (Corporate Real Estate Management) were ranked the $3^{\text {rd }}, 4^{\text {th }}, 5^{\text {th }}$ and $6^{\text {th }}$ level of use with RII of 2.82, 2.59, 2.25 and 1.92 respectively. GIS, Argus Valuation-DCF, Eva Property.com, Apartment ManagerXp, and Artificial Intelligence Software showed the $7^{\text {th }}, 7^{\text {th }}, 9^{\text {th }}, 9^{\text {th }}$ and $9^{\text {th }}$ positions at the bottom of the ranking table with RII of 1.87, 1.87, 1.00, 1.00 and 1.00 respectively. Valuation is the core section in the Practice of estate surveying and valuation. The findings showed the level of use of the software that applies to the section to ease the conventional workload in the section.

Table 7e: Drawing of Sketches

\begin{tabular}{|c|c|c|c|c|c|c|c|c|}
\hline DETERMINANTS & & $\begin{array}{l}\mathrm{HU} \\
(5)\end{array}$ & $\begin{array}{l}\mathrm{U} \\
(4)\end{array}$ & $\begin{array}{c} \\
(3)\end{array}$ & $\begin{array}{l}\text { RU } \\
(2)\end{array}$ & $\begin{array}{l}\mathrm{NU} \\
(1)\end{array}$ & RII & $\begin{array}{l}\text { RANKIN } \\
\text { G }\end{array}$ \\
\hline AutoCAD & & 200 & 128 & - & 10 & 2 & 4.30 & $1^{\mathrm{ST}}$ \\
\hline Corel Draw & & 180 & 136 & - & 8 & 5 & 4.16 & $2^{\text {nd }}$ \\
\hline GIS & & 10 & - & 12 & 46 & 50 & 1.49 & $3^{\text {rd }}$ \\
\hline MS Office Package & & 20 & 12 & - & 22 & 61 & 1.46 & $4^{\text {th }}$ \\
\hline MS Excel & & 15 & 4 & - & 10 & 70 & 1.25 & $5^{\text {th }}$ \\
\hline Argus Valuation-DCF & & - & - & - & 4 & 77 & 1.03 & $6^{\text {th }}$ \\
\hline $\begin{array}{l}\text { CRM (Corporate Real } \\
\text { Management }\end{array}$ & Estate & - & - & - & - & 79 & 1.00 & $7^{\text {th }}$ \\
\hline Data Base Management & & - & - & - & - & 79 & 1.00 & $7^{\text {th }}$ \\
\hline Eva Property.com & & - & - & - & - & 79 & 1.00 & $7^{\text {th }}$ \\
\hline Apartment ManagerXP & & - & - & - & - & 79 & 1.00 & $7^{\text {th }}$ \\
\hline Artificial Intelligence Software & & - & - & - & - & 79 & 1.00 & $7^{\text {th }}$ \\
\hline
\end{tabular}

Source: Field Survey, 2020

Table 7e shows analysis of responses on the use of software as its applicable in eEstate surveying \& valuation practice in drawing of sketches. Some of the major real estate software listed 
e-issn: $2229-8568$

were ranked and the findings show that AutoCAD, was ranked first with RII of 4.30, along with Corel Draw which was ranked $2^{\text {nd }}$ ( RII of 4.16). However, GIS, MS Office Package, MS Excel, and Argus Valuation-DCF were ranked the $3^{\text {rd }}, 4^{\text {th }}, 5^{\text {th }}$ and $6^{\text {th }}$ level of use with RII of $1.49,1.46,1.25$ and 1.03 respectively, while CRM (Corporate Real Estate Management, Eva Property.com, Apartment ManagerXp, and Artificial Intelligence Software showed the $7^{\text {th }}, 7^{\text {th }}, 7^{\text {th }}, 7^{\text {th }}$ and $7^{\text {th }}$ position at the bottom of the ranking table with RII of 1.00, 1.00, 1.00, 1.00 and 1.00 respectively. The result shows the rate of the importance of the software for drawing sketches either for valuation exercise or property/project development. Out of this result, we can see the most used software to least software in the section.

Table 7f: D C F Valuation

\begin{tabular}{|c|c|c|c|c|c|c|c|c|}
\hline DETERMINANTS & & $\begin{array}{l}\mathrm{HU} \\
(5)\end{array}$ & $\begin{array}{c}\mathrm{U} \\
(4)\end{array}$ & $\begin{array}{c}\text { I } \\
(3)\end{array}$ & $\begin{array}{l}\text { RU } \\
(2)\end{array}$ & $\begin{array}{l}\text { NU } \\
(1)\end{array}$ & RII & $\begin{array}{c}\text { RANKIN } \\
\text { G }\end{array}$ \\
\hline MS Excel & & 190 & 124 & - & 20 & - & 4.23 & $1^{\mathrm{ST}}$ \\
\hline Argus Valuation-DCF & & 95 & 144 & 15 & 12 & 13 & 3.53. & $2^{\text {nd }}$ \\
\hline MS Office Package & & 70 & 72 & 9 & 28 & 30 & 2.65 & $3^{\text {rd }}$ \\
\hline Data Base Management & & 15 & 36 & - & 24 & 55 & 1.65 & $4^{\text {th }}$ \\
\hline Corel Draw & & - & - & 30 & 8 & 65 & 1.30 & $5^{\text {th }}$ \\
\hline GIS & & - & - & - & - & 79 & 1.00 & $6^{\text {th }}$ \\
\hline AutoCAD & & - & - & - & - & 79 & 1.00 & $6^{\text {th }}$ \\
\hline $\begin{array}{l}\text { CRM (Corporate Real } \\
\text { Management }\end{array}$ & Estate & - & - & - & - & 79 & 1.00 & $6^{\text {th }}$ \\
\hline Eva Property.com & & - & - & - & - & 79 & 1.00 & $6^{\text {th }}$ \\
\hline Apartment ManagerXP & & - & - & - & - & 79 & 1.00 & $6^{\text {th }}$ \\
\hline Artificial Intelligence Software & & - & - & - & - & 79 & 1.00 & $6^{\text {th }}$ \\
\hline
\end{tabular}

Source: Field Survey, 2020

Table $7 \mathrm{f}$ shows an analysis of responses on the use of software for D C F Valuation. The major real estate softwares listed were ranked and the study showed that MS Excel, was ranked first, with RII of 4.23, along Argus Valuation-DCF which was ranked $2^{\text {nd }}$ having RII of 3.53. However, MS Office Package, Data Base Management, Corel Draw, and AutoCAD were ranked the $3^{\text {rd }}, 4^{\text {th }}, 5^{\text {th }}$ and $6^{\text {th }}$ level of use with RII of 2.65, 1.65, 1.30 and 1.00 respectively, GIS, CRM (Corporate Real Estate Management, Eva Property.com, Apartment ManagerXp, and Artificial Intelligence Software were ranked the $6^{\text {th }}, 6^{\text {th }}, 6^{\text {th }}, 6^{\text {th }}$ and $6^{\text {th }}$ positions at the bottom of the ranking table with RII of $1.00,1.00,1.00,1.00$ and 1.00 respectively. From the field of estate surveying and valuation practice in the country, it is clear that real estate investment is among the objective in the practice. To value some of this real estate investment, discounted cash flow method of valuation is being used. To reconsider the use of the conventional method in carrying out the exercise, the analysis determines the level of usage of the various software that applies to the section and a conclusion can be drawn from the result gathered on the importance of the software from the most utilised to the less utilised.

Table 8: Challenges Faced by Firm Due to the Use of I.C.T Tools in Estate Surveying \& Valuation Practice

\begin{tabular}{lcl}
\hline Challenges & Mean & Rank \\
\hline Inadequate Training & 3.99 & $1^{\text {st }}$ \\
Inadequate Supply of Power & 3.87 & $2^{\text {nd }}$ \\
Shortage of Skilled Manpower & 3.81 & $3^{\text {rd }}$ \\
MS Access & 3.80 & $4^{\text {th }}$ \\
Rapid Changes in ICT & 3.70 & $5^{\text {th }}$ \\
High Cost of Acquisition & 3.68 & $6^{\text {th }}$ \\
Fear of Virus Attack & 3.53 & $7^{\text {th }}$ \\
Time Consuming & 2.96 & $8^{\text {th }}$ \\
Some give Inaccurate Result & 2.86 & $9^{\text {th }}$ \\
\hline
\end{tabular}

Source: Field Survey, 2020 
Table 8 shows the most significant challenge faced by professionals. It is found that inadequate training towards the usage of ICT in providing estate surveying and valuation services was ranked the highest with a mean of 3.99 and the lowest ranked challenge was ICT sometimes give inaccurate result. Inadequate supply of power was identified as the second most significant challenge with a mean of 3.87followed by the following challenges: shortage of skilled manpower, d MS Access, rapid changes in ICT, high cost of acquisition, of virus attack and 2.96 were ascribed to time consuming. It shows vividly that majority of the respondent disagrees with the fact that some ICT give inaccurate result as well as time consuming. This will help the researchers to assess the level of usage of the ICT in estate surveying and valuation practice.

Table 9: Positive Effect of the Adaptation and Use of I.C.T. on Estate Surveying and Valuation Practice

\begin{tabular}{lcc}
\hline Possible Advantages & Mean & Mean Rank \\
\hline Time Saving & 4.81 & $1^{\text {st }}$ \\
Makes Job Easier & 4.49 & $2^{\text {nd }}$ \\
Helps Document Presentation & 4.40 & $3^{\text {rd }}$ \\
Makes Information Transfer Easier & 4.38 & $4^{\text {th }}$ \\
Enhances Accuracy & 4.30 & $5^{\text {th }}$ \\
Attract More Client & 4.18 & $6^{\text {th }}$ \\
Reduction in Staff Requirement & 4.17 & $7^{\text {th }}$ \\
Increases Productivity & 4.05 & $8^{\text {th }}$ \\
Enhances Management Decision & 3.81 & $9^{\text {th }}$ \\
\hline
\end{tabular}

Source: Field Survey, 2020

Table 9 shows that the most advantageous factor in using ICT in estate surveying and valuation practice is time saving while enhanced management decision being the least advantageous factor to professionals. The second most significant advantage is ICT makes the job easier while the third most advantageous is ICT helps document presentation. The analysis showed the positive effect of the use of ICT in the field of estate surveying and valuation practice and thus will help the researchers to check the level of usage of ICT in the field of practice.

\subsection{Correlation Analysis}

Table 10 shows the correlation between the contribution of ICT in estate surveying and valuation practice and the performance alongside the size of the firms is assessed. A high positive coefficient of correlation was derived at 0.6604 indicated that the contribution of information and communication technology has a significant effect on real estate. In essence the larger the size of the real estate firm, the more dependent that firm is on the use of I.C.T tools.

Table 10: Correlation between the Contribution of I.C.T towards the Improvement of Estate Surveying \& Valuation Practice and the Performance alongside the Size of the Firms

\begin{tabular}{llc}
\hline Variables & \multicolumn{2}{c}{ Correlation Co-efficient } \\
\hline $\begin{array}{l}\text { Contribution of I.C.T towards } \\
\text { improving Real Estate Practice }\end{array}$ & $\begin{array}{l}\text { Pearson Correlation } \\
\text { Sig. (2-tailed) }\end{array}$ & 0.6604 \\
Size of the firms & $\mathrm{N}$ & 79 \\
\hline
\end{tabular}

Source: Field Survey, January 2020 
e-issn: $2229-8568$

\subsection{DISCUSSION}

From the findings from the descriptive analysis, RII and correlation analysis the following discussion can be made. The identification of the different ICT tools that are used and applicable to estate surveying and valuation practice was made. The ICT tools are computers, projectors, printers etc. among the real estate firm in the study area. The analysis showed that ICT has contributed immensely to the development and growth of real estate practices in the study area. All the respondents claimed that ICT has been generally accepted and also contribute greatly to the performance of the real estate practice. However, the adoption of ICT in the in providing estate surveying and valuation services faces many challenges. Inadequate training towards the usage of ICT in providing estate surveying and valuation services rank so high and this implies that there is a huge gap in the area of deployment of requisite know-how for the full realisation of the potential that can be impacted upon real estate practice.

\subsection{CONCLUSION AND RECOMMENDATION}

The research on the assessment of ICT usage in estate surveying and valuation practice in the study area has shown that the use of ICT has brought about a stark improvement in the quality of the practices and services they render to clients along with an ease in work schedule as well as improvement in record keeping. The findings further ensured that ICT devises took a very optimistic and significant consequence on the estate surveying and valuation practice and the need to further apply ICT into the real estate profession is imperative.

Furthermore, the study showed that the level of application of ICT in estate surveying and valuation has been very significant, but there are still barriers that limit its application within the sector. Finally, the study revealed the nature of ICT and its effect on the practice has significant positive effect on estate surveying and valuation practice as well as the profession in general and should therefore be encouraged to ensure future growth with the estate surveying \& valuation practice. In the light of the earlier conclusion, the following submissions are tendered to safeguard that estate surveying and valuation practitioners to grip the usage or submission of ICT in numerous estate surveying and valuation practices.

The Government should equip higher institutions of learning with adequate ICT tools needed to train estate management students in other to boost I.C.T use in real estate. The Government should also support the Nigeria Institution of Estate Surveyors and Valuers (NIESV) to make ICT more important, appreciated, useful, relevant, and easily understood in estate surveying and valuation practice. As such, there is the necessity to mainstream appropriate ICT topics and programmed into every specific course to be compulsory in such a manner that the students can grip and apply the procedures in a supportable and expressive way. Government should educate estate surveyors through NIESV and ESVARBON on the vital requirement for the growth of professional software as well as hardware packages in estate surveying and valuation practice that will precisely replicate the indigenous repetition technique.

\subsection{REFERENCE}

1. Adedamola, W. A. (2020), Assessment of ICT in Estate Surveying and Valuation Practice in Lagos Island, Nigeria (Unpublished Degree Thesis). Bells University of Technology Ota,Ogun State, Nigeria.

2. Asika, N. (2014). "Research Methodology in Behavioral Sciences: Lagos" Longman Publishing Limited Banks and Other Financial Institutions Act 1991.

3. Babawale, G. K. (2012). Paradigm shift in investment property valuation theory and practice: Nigerian practitioner's response. Mediterranean Journal of Social Sciences, 3(3) 217-228. 
e-issn: $2229-8568$

4. Babatunde, T.O., Ajayi, C.A. (2018) "The impact of information and communication technology on real estate agency in Lagos Metropolis, Nigeria", Property Management, 36(2) 173-185. https://doi.org/10.1108/PM-10-2016-0057

5. Confederation of Indian Industry (2012): An effective and Efficiently use of Technology present at The Global Information Technology Report 2012 Living in a Hyperconnected World at World Economic Forum

6. Dixon T. (2005). The Impact of Information and Communication Technology on Commercial Real Estate in the Economy. Journal of Property Investment and Finance, 23(6) 480 - 493

7. Ibisola, S.A., Oni, A.S. and Pete, J.K. (2015). The Relevance and Application of ICT in Estate Surveying and Valuation in Ogun State. International Conference on African Development Issues (CU-ICAD) 2015: Information and Communication Technology Track

8. Ikemefuna .C.O. (2005): Management Theory \& practice. Concept Publications, Lagos Nigeria.

9. Kakulu, 1. (2008); A Computerized Approach Real Estate Practice in Nigeria: IBK Publications, Port-Harcourt.

10. Kirkwood J. S. (2003). Urban Real Estate Information Systems: The Suppression of Radical Innovation. School of Environment and Development, Sheffield Hallam University, UK.

11. Nigerian Institution of Estate Surveyors and Valuers Code of Professional Ethics and Practice.

12. Ogunsola, L. A. and Aboyade, W. A. (2005). Information and communications technology in Nigeria: Revolution or evolution. Journal of Social Science, 11(1) 7-14.

13. Olukolajo, M.A, Ojo, B. and Akinwamide, D.O. (2015). Assessment of use of social media in real estate transactions in Lagos property market. American Journal of Economics, Finance and Management, 1(2) 63-68

14. Oyetunji, B.O., Ojo, B., and Oyetunji, K.A. (2018). ICT Utilization Status and Challenges in the Nigerian Real Estate Practice. Journal of Information Science, Systems and Technology, 2(2) 2839

15. Real Estate Insight (2010). Real estate developers - Finding ways out of the financial crisis through tax and innovation strategies. Alitheia Capital Limited, Lagos Nigeria. (Retrieved on December 14, 2019).

16. Reijo, S., Elias, J., Jouko, K., Miettinen, I. and Jussi, K. (2005). ICT as an enabler for conversion of real estate business to customer focused workplace industry. Helsinki, Sweden: Software Business and Engineering Institute (SoberIT). Helsinki University of Technology (HUT).

17. Reijo, S., Elias, J., Jouko, K., Miettinen, I. and Gersberg, N. (2007). ICT as an enabler for conversion of real estate business to customer focused workplace industry. Helsinki, Sweden: Software Business and Engineering Institute (SoberIT). Helsinki University of Technology (HUT).

18. Rodriguez, F. \& Wilson, E. (2002).“Are Poor Countries Losing the Information Revolution?” InfoDev Working Paper, Washington D. C; World Bank

19. Sawyer, S., Wigand, R. T., and Crowston, K. (2005). Redefining access: Uses and roles of information and communication technologies in the US residential real estate industry from 1995 to 2005. Journal of Information Technology, 20(4) 213-223.

20. Sawyer, S., Wigand, R. T., Crowston, K. and Allbritton, M., (2003). The social embeddedness of 
transactions: Evidence from the residential real estate industry. The Information Society, 19(2) 135154

21. Sing, T. F. (2002) Impact of Information \& Communication Technology (ICT) on Office Demand in Singapore CBD. Paper presented to Association for Project Management (APM). Centre for Real Estate Studies. Department of Real Estate, NUS.

22. Tse R. Y. \& Webb J. (2002) Real Estate Technology. University of Florida: Department of Geography. Gainesville, FI 33611. 